\title{
News and Notices
}

\section{The European Jesuit Libraries Provenance Project}

\author{
Kathleen M. Comerford \\ Georgia Southern University \\ kcomerfo@georgiasouthern.edu
}

\begin{abstract}
The European Jesuit Libraries Provenance Project is a census of books once owned by a Jesuit college or house in Europe between the 1550s and 1773. The suppression of the Society of Jesus led to the dispersal of its books, and the EJLPP uses both manuscript inventories and searches in modern libraries to locate the volumes once associated with the Society of Jesus. It is multimedia, digital humanities endeavor, supervised by Kathleen M. Comerford and employing student interns at Georgia Southern University.
\end{abstract}

\section{Keywords}

Digital humanities - Dominus ac redemptor noster - Belgium - central Italy Barcelona - Yale University - Princeton University - Folger Shakespeare Library public history

The 1773 papal bull "Dominus ac redemptor noster," issued by Clement XIV $\left(1705^{-74}\right.$, r.1769-74), formally disbanded the global Society of Jesus after a 
series of controversies and several local suppressions. ${ }^{1}$ In part, the bull read: "We deprive it [the Society] of all activity whatever, of its houses, schools, colleges, hospitals, lands, and, in short, every other place whatsoever, in whatever kingdom or province they may be situated."2 One immediate result of the bull was the inventorying of property at the Jesuit houses and colleges (including real estate, furniture, and books), in preparation for the sale or transfer of that property. This echoed the response to earlier, more local, actions against the Society; for example in Portugal, the first European country to suppress the Society, King João VI (1767-1826, r.1816-26) issued a royal charter on January 19, 1759 , ordering royal officials to take possession of "all the property and goods of the Society of Jesus," after overseeing an inventory of "the cells, libraries, refectory, etc.; a cataloguing that extended to all movable and immovable property linked to each house."3

Many of those inventories have been preserved, and provide modern scholars with ways to understand the operation of Jesuit colleges and houses prior to the suppression. While our knowledge of the Ratio studiorum, the Jesuit curriculum formally established in 1599, is broad, and the teaching and scholarly accomplishments of some academic superstars among the early Jesuits have been explored at length, we know less about the ways in which the more ordinary members of the Society, and the young men they taught, pursued, and collected knowledge. With this in mind, I began to investigate Jesuit library collections as a method of better understanding the education, intellectual life, spiritual influence, and global impact of the Society of Jesus. I started by comparing the inventories from Florence and Siena in the sixteenth century to Antonio Possevino's Bibliotheca selecta, and incorporated some of that research into a 2013 article and my book Jesuit Foundations and Medici Power, 1532-1621. ${ }^{4}$ While I was completing the monograph, Thomas McCoog, S.J., asked

1 Clemens PP. XIV. ad perpetuam rei memoriam: Dominus ac Redemptor noster Jesus Christus (Rome: 1773), at https://archive.org/details/clemensppxivadpeoocath (accessed November 10, 2019).

2 Partial English translation from http://www.reformation.org/jesuit-suppression-bull.html (accessed November 10, 2019).

3 Mar García Arenas, "Una aproximación a la represión pombalina sobre el entorno social de la Compañía de Jesús: El caso de los colaboradores de los jesuitas del Hospicio de São Francisco de Borja de Lisboa (1760-1761)," Lusitania sacra 32 (2015): 121-45, here 123 ("todas las propiedades y bienes de la Compañía de Jesús") and 125 ("las celdas, las bibliotecas, el refectorio, etc., una catalogación que se extendía a todos los bienes muebles e inmuebles ligados a cada casa").

4 Archivio di Stato di Firenze, Compagnie Religiose Soppresse da Pietro Leopoldo (henceforth ASF CRSPL) 999, Filza 3, n. 104: Collegio S. Giovanni Evangelista, Firenze. Inventario di tutti i 
me to present a talk about the Jesuit library of what became Heythrop College at the University of London (2014), and Robert Maryks asked me to edit a special issue of the Journal of Jesuit Studies on Jesuit libraries (issue 2, no. 2, 2015). ${ }^{5}$ Since then, I have engaged in provenance research at several institutions, and have received funding from Yale University's Beinecke Library (2016) and the Princeton University Library (2018). The work I completed there, at the Folger Shakespeare Library in Washington, DC, and at archives and libraries in central Italy, northern Spain, and north-central Belgium, forms the backbone of the European Jesuit Libraries Provenance Project, a census of books once held by colleges and houses administered by the pre-suppression Society of Jesus in Europe. The EJLPP is a multimedia and digital humanities endeavor, using modern technologies to collect, process, and analyze information from the sixteenth, seventeenth, and eighteenth centuries.

My initial goal was to write a broad history of Jesuit college libraries. I attempted to determine the contents of specific libraries over time, in an endeavor similar to the work of such scholars as Paul Begheyn, Pierre Guérin, and Klára Jakó, who have worked to reconstruct the libraries of Jesuit colleges in Delft, Liège, and Cluj during the early history of the Society of Jesus. ${ }^{6}$ I have

beni mobili di Casa fatto a 1.o di X.bre di 1578 per ordine di'l P. Sebastiano Morales Visitatore della Provincia della Toscana (729 titles); Archivum Romanum Societatis Iesu (henceforth ARSI) Rom 121, fols. $148^{\mathrm{r}}-15^{\mathrm{v}}$ : Inventario delli libri del Collegio de Fiorenza fatto a dj $15 \mathrm{di}$ Febraro 1566 [i.e. 1565] (421 titles); ARsI Rom 124 I, fols. $235^{\mathrm{r}}-23^{\mathrm{v}}$ : Catalogo de libri Theologi del Collegio di Siena 1565 (201 titles); and Antonio Possevino, Bibliotheca selecta qua agitur de ratione studiorum in historia, in disciplinis, in salute omnium procuranda (Rome: Typographia Apostolica Vaticana, 1593; Venice: Altobello Salicato, 1603 and Cologne: Joannes Gymnich, 1607). See Kathleen M. Comerford, "Jesuit Tuscan Libraries of the 156os and 1570s: Bibliotheca not-yet selecta," Archivum historicum Societatis Iesu 162 (2013): 515-53, and Comerford, Jesuit Foundations and Medici Power, 1532-1621 (Leiden: Brill, 2017).

5 Kathleen M. Comerford, ed., special issue "Jesuits and Their Books," Journal of Jesuit Studies 2, no. 2 (2015), https://brill.com/view/journals/jjs/2/2/jjs.2.issue-2.xml (accessed November 9, 2019). My unpublished Heythrop College talk, delivered on June 19, 2014, was entitled "Jesuits and Their Libraries."

6 See, for example, Paul Begheyn, "The Oldest Jesuit Library Catalogue in the Dutch Republic: The Book Collection at Delft (1614)," in Emblematic Images and Religious Texts: Studies in Honor of G. Richard Dimler, S.J., ed. Pedro F. Campa and Peter M. Daly (Philadelphia: Saint Joseph's University Press, 2010), 71-86; Pierre Guérin, Les jésuites du Collège Wallon de Liège durant l'ancien régime (Liège: Société des Bibliophiles Liégeois, Société royale, 1999), 1:26; and Klára Jakó, "Az elsö kolozvári egyetemi konyvtar törtenete és állományák rekonstruckcioja 1579-1604" [Reconstruction of the history and collection of the first university library of Kolozsvár [Cluj], 1579-1604], Erdélyi Könyvesházak I, Adattár XVI-XVII: Századi szellemi mozgalmaink történetéhez [Transylvanian book houses I, database sixteenth-seventeenth 
collected manuscript book lists from cities in Italy and Belgium, and have to date transcribed eight of these (one each in Bagnacavallo, Bologna, Siena, and Leuven, and two in Florence and Antwerp). These inventories, which vary considerably in length, have thus far proven useful in two principal ways: first, I have studied each in some detail to understand the local and comparative histories, for example to determine which books were more popular in certain areas, which subjects or languages dominate in a given region, etc. ${ }^{7}$ The most important limiting factors here are that an inventory created in the 1770 s tells little about book collection or preservation practices over the long run, and that even lengthy book lists consist of very brief, and often quite vague or misleading, notations regarding the books, sometimes written by scribes with identifiable hearing or writing difficulties. Perhaps the most frustrating references are from the college of Antwerp in 1613: "Auctores pro $1^{\circ}$ anno," "Auctores graecae," etc., with no hints at how many volumes or authors are grouped together. As a result, we will never be able to identify every title in these lists.

The second use I have made of these inventories is to create lists of books to request in searches for provenance marks that were not catalogued and for the actual artifacts: specific volumes once held by Jesuit colleges. The inventories

centuries: the history of our spiritual movements of the twentieth century] 16 (Szeged: Scriptum, 1991). I am grateful to Éva Szeli of Arizona State University for her help in translating this title. I attempted to reconstruct a portion of the Roman College library in "Teaching Priests to be Pastors: Comparing Jesuit Schools and Diocesan Seminaries in Seventeenth-Century Italy," Archivum historicum Societatis Iesu 72 (2003): 297-322.

7 The inventories I have collected are: Rijksarchief Antwerpen, Archief Nederduitse Jezuïetenprovincie (Flandro Belgica) (henceforth RA/ANJ [fb]) 2045: Stukken betreffende een proces voor de Geheime Raad tussen Joachim Trognesius, boekdrukker in Antwerpen, aanleggen en de provincie, verweerder, over het drukken van boeken voor de Sociëteit, 1613 (153 titles). RA/ANJ (FB) 2046: Catalogus van de boeken over architectuur, achtergelaten door P. Guilielmus Cornelii, overleden te Leuven in 1660 (39 titles). RA/ANJ (FB) 3278: Bibliotheekcatalogus. S.d.; this is probably the one Ria Fabri and Piet Lombaerde called incomplete from 1730 in their "Appendix I. Architectural Treatises, Books and Prints in the Libraries of the Jesuits in Antwerp," in Innovation and Experience in the Early Baroque in the Southern Netherlands: The Case of the Jesuit Church in Antwerp, ed. Piet Lombaerde (Turnhout: Brepols, 2008), 187200, here 189, based on their discovery of books with Jesuit provenance markings in the Royal Library in Brussels. Rijksarchief Leuven, Jezuïeten College Leuven 20. Catalogus van de schenkingen aan de bibliotheek, 1635 (613 titles). Archivio Arcivescovile di Bologna 244, Libreria, Missioni, Patronati. Archivio Comunale di Ferrara, Ex Patrimonio Gesuitico 78: Descriptio Bibliotecae Excollegi Societatis Iesu Balneocaballi (Bagno Cavallo) (1,061 titles). ASF CRSPL, Gesuiti di Livorno. Inventario dei Libri, Fogli, Documenti, attenenti all'Istoria, Diritti, Ragioni, ed Azienda del già Collegio della Compagnia di Gesù di Livorno (1773-1775) (189 titles). 
from the time of the suppression do not provide information on the fate of the items once owned by the Jesuits when they were forced to relinquish their properties. We know that movable properties from the colleges and houses, including books, were scattered: some volumes went to state libraries (for example, those of the colleges near the cities of Palermo and Parma), ${ }^{8}$ some to universities (e.g. Novara and Cagliari), ${ }^{9}$ and still others to different religious foundations (e.g. the Hospitallers in Bavaria). ${ }^{10}$ Thus, the history of the Jesuit books, not just the libraries, requires investigating modern library cataloguing as well as archival documents of pre-modern inventories. I began this aspect of my research at the Beinecke in 2016 and have since sought provenance information at the Folger Shakespeare Library, the libraries of Princeton, Georgetown, and Emory Universities and the University of Maryland, the Biblioteca Pública Episcopal del Seminario de Barcelona, and the Universidad de Barcelona. In addition, I have used the title and author information for searches in the vast collections of books scanned by Google, Hathitrust, the Internet Archive, and the Bayerische Staatsbibliothek, and online catalogues of libraries in England, Scotland, Spain, Italy, and the United States.

These efforts depend on preservation of archival and printed materials, and there can be no doubt that we have lost much evidence over the centuries. While secular authorities were dismantling collections as a result of the suppressions, those who had until that time been Jesuits made attempts to stop the plunder, and in so doing also caused damage. Institutions in Spanish Italy

8 Domenico Ciccarello and Laura Mattaliano, "Le biblioteche dei gesuiti," "Mediaeval Sophia," Studi e ricerche sui saperi medievali 15-16 (2014): 209-12, here 209-10, http://www .mediaevalsophia.net/_fascicoli/15-16/209-212-ciccarello-mattaliano_ms15-16.pdf (accessed November 11, 2019). Via a search of library catalogues, one can also establish, for example, that many of the books from Belgian Jesuit colleges were sent to the Royal Library of Brussels, and those from Bohemian colleges were sent to the National Library of the Czech Republic in Prague.

9 Christopher Storrs, "The Suppression of the Jesuits in the Savoyard State," 139-6o, in The Jesuit Suppression in Global Context: Causes, Events, and Consequences, ed. Jeffrey D. Burson and Jonathan Wright (New York: Cambridge University Press, 2015), here 154-56; Dorino Tuniz, "Le biblioteche del collegio dei gesuiti di Novara," in La Compagnia di Gesù e la società piemontese: Le fondazioni del Piemonte orientale, ed. Bruno Signorelli and Pietro Uscello (Vercelli: Gallo Arti Grafiche, 1995), 105-14; and Giovanna Granata, "The Collection of Montserrat Rosselló in the University Library of Cagliari," Journal of Library and Information Sciences 9 (2018): 53-73.

10 David F. Allen, "Upholding Tradition: Benedict XIV and the Hospitaller Order of St. John of Jerusalem at Malta, 1740-1758," Catholic Historical Review 8o (1994): 18-35, here 29 and 34 , noted that Clement XIV had approved the diversion of Jesuit resources to the support of the university as early as 1769 . 
provide examples of the endangered Society's struggle to maintain control over its property and to prevent the local civic rulers from taking it away. Juan Antonio Alejandre García and María Jesús Torquemada Sánchez have demonstrated that, at least in Naples, members of the Society were quite anxious as the suppressions spread throughout Spanish territories. They note that the prime minister of Naples, Marquis Bernardo Tanucci (1698-1783), wrote in December 1767 to Domenico Orsini d'Aragona (1719-89), cardinal protector of the Kingdom of Two Sicilies from 1748 to 1789 , arguing that action by the state to take possession of the property of the Society

should not be delayed, since it was assumed that once the Jesuits began to suspect that an expulsion project was being prepared against them, they would seek to dispose of important books and documents to identify their possessions, to sell their plate, belongings and every kind of product, and to transfer the proceeds [from the sales] to safer locations. ${ }^{11}$

The government saw potential financial, not just material, gains, as (despite objections from Rome) it intended to raise funds to create new schools to replace those formerly run by the Society, by seizing the contents of the existing schools and selling them. Cardinal Vittorio Maria Baldassare Gaetano Costa d'Avignano (1737-96), then bishop of Vercelli (1769-78), also under Spanish control, requested both money and books from the suppressed Jesuit houses to support the nearby bishopric of Biella, recently created (1772). Local Jesuits in Sicily successfully hid some of their assets and belongings. ${ }^{12}$ Similar cases of obstruction can be found elsewhere in Europe. For example, Hendrik Callewier has identified both financial fraud and "a systematic destruction of archival materials" during the 1773 process of suppression in the Austrian Low

11 Juan Antonio Alejandre García and María Jesús Torquemada Sánchez, "La expulsión de los jesuitas del Reino de Nápoles: Algo más que una obsesión," Cuadernos de historia del derecho 7 (2000): 223-307, here 268 ("Se trataba, en todo caso, de una actuación que no debía demorarse, pues era de suponer que desde que los jesuitas comenzaron a sospechar que contra ellos se preparaba un proyecto de expulsión estarían tratando de deshacerse de libros y documentos importantes para identificar sus posesiones, de vender joyas, enseres y toda clase de productos y de transferir lo obtenido a lugares más seguros") and 268n123. I am grateful to my Georgia Southern University colleague Letitia McGrath for her help with this translation. The royal commission's October 25,1767 decision regarding the suppression took special aim at the books written by Jesuits, saying nothing about the libraries or the collection of books written by other authors.

12 Alejandre García and Torquemada Sánchez, "Expulsión de los jesuitas del Reino de Nápoles," 269-70. 
Countries..$^{13}$ Since Jesuit librarians, superiors, and other administrators sought to resist such dramatic losses, it is likely that at least some of them provided false information on some inventories, perhaps keeping books for themselves or selling them. On the other hand, some of those charged with transferring volumes to other institutions certainly damaged, destroyed, sold, or lost some along the way, as happened to the English college in St. Omer. ${ }^{14}$ In the face of both panic and greed, we should assume that some books were lost entirely in many, if not all, provinces, and thus caution that the inventories taken around 1773 likely do not properly reflect the contents of a given college. The books remained vulnerable throughout the following centuries. The fate of the library of the Katholieke Universiteit Leuven, burned in 1914 by German soldiers, rebuilt and restocked in the 1920s, and burned again in 1940, is an extreme illustration of the kinds of devastation that could befall an institutional library in the course of modern warfare. ${ }^{15}$

It is thus far easier to talk about the general purposes and contents of the libraries. Information gleaned from inventories or provenance markings is quite useful in the quantitative history of books and readers, as this methodology's

objective is the understanding of a general cultural, social, and economic situation [...]. It is not as interested in specific locations of particular inventoried volumes, but rather in generalities that can be drawn about book possession, and uses those generalities to depict social interests and tendencies and what and how people thought. ${ }^{16}$

13 Hendrik Callewier, “The Foundation of All Our Affairs': A History of the Archives of the Old Jesuit Order in the Southern Low Countries," Archives et bibliothèques de Belgique/ Archief- en bibliotheekwezen in België 8o (2009): 191-209, here 213, 221.

14 The transfer of books and other possessions in from St. Omer to Bruges in 1762 , and then in 1773 from Jesuit to Dominican ownership, did not protect that property for long. In 1794, the effects of the French Revolution led to the exile of the remaining former Jesuits to England. To pay for the trip, they had to sell books, plate, and relics. George Gruggen and Joseph Keating, Stonyhurst: Its Past History and Life in the Present (London: Kegan Paul, Trench, Trubner and Co., 1906), 43; Janet Graffius, "St. Omers to Stonyhurst: Jesuit Education of English Catholics 1593-1900," in Catholic Collecting/Catholic Reflection, 1538-1850, ed. Virginia Chieffo Raguin (Worcester, MA: College of the Holy Cross, Cantor Art Gallery, 2006), 161-68, here 165; and John Gerard, Memorials of Stonyhurst College (London: Burns and Oates, 1881), 41.

15 Cf. Frans Gistelinck and Maurits Sabbe, eds. Early Sixteenth-Century Printed Books, 15011540 in the Library of the Leuven Faculty of Theology (Leuven: Bibliotheek Godgeleerdheid: Uitgeverij Peeters, 1994).

16 Benito Rial, "Sixteenth-Century Private Book Inventories and Some Problems Related to Their Analysis," Library and Information History 26, no. 1 (2010): 70-82, here 71. 
Examples of such analysis according to subject include Bart op de Beeck's examination of the library of the Jesuit college of Brussels and Anna Dymmel and Piotr Dymmel's recreation of the collection of the pre-suppression Lublin Jesuits (the church and school of what is now the Cathedral of St.John the Baptist with the collegiate church of St. Michael and the residence at Our Lady of Loreto in Chodel, outside the city of Lublin, Poland). ${ }^{17}$ As a result of these concerns, I broadened my focus on Jesuit libraries to search not only for books identified as once belonging to one or more of the inventories I have collected, but for as many volumes with Jesuit provenance indications as I could track down.

Having amassed a large data set, in August 2018, I launched the EJLPP via a web page, Instagram feed, Facebook page, and Flickr photostream. ${ }^{18}$ The data set, which is continually expanding, is in large part public, because no one scholar or group of scholars will be able to exploit all of the possibilities in such a compilation and thus to do a genuinely quantitative history of books and readers. As of this writing, we have records for over 4,500 individual volumes with European Jesuit provenance. In addition to the financial support from Yale and Princeton Universities, the project has received backing from the Public History program at Georgia Southern University, which has allowed me to employ five undergraduate and two graduate students as credit earning interns since August 2018. We have been featured in a French-language blog on the website of the Société bibliographique de France. ${ }^{19}$ We are in the process of constructing an archive at the Digital Commons platform of Georgia Southern University (Statesboro campus). ${ }^{20}$ Yale's Beinecke and Law Libraries, the Folger Shakespeare Library, and the Emory University libraries have allowed me to

17 Bart op de Beeck, "De bibliotheek van het Brusselse Jezuïetencollege tijdens het Ancien Régime," in Quatre siècles de présence jésuite in Quatre siècles à Bruxelles, ed. Alain Deneef (Brussels: Éditions Prosopon and Leuven: KADOC, 2012), 49-89, here 54. In Lublin, all copies of the 1773 inventory were destroyed before or during World War II, so the authors relied on multiple documents, including what appear to be notes for future study collected by Fr. Ludwik Zalewski, S.J. (1878-1952). Anna Dymmel and Piotr Dymmel, "Biblioteka kolegium jezuitów w Lublinie i jej losy," Archiwa, biblioteki i muzea kościelne 109 (2018): 135-68, here $137-38$.

18 www.jesuit-libraries.com, https://www.instagram.com/jesuitprovenance/?hl=en, https:// www.facebook.com/EuropeanJesuitLibraries/?modal=admin_todo_tour, and https:// www.flickr.com/people/142229640@No8/ (accessed November 11, 2019).

19 Kathleen M. Comerford and Rudy Bond, "Les provenances des bibliothèques jésuites européennes," and translated by Malcolm Walsby, at https://histoirelivre.hypotheses .org/2864 (accessed November 10, 2019).

20 https://digitalcommons.georgiasouthern.edu/jesuit-lib-images/ (accessed November 10, 2019) is still under construction but is available for consultation. 
use my own photographs of volumes in their collections in my digital media sites and publications, providing access to data including marginalia, provenance markings, and information on the physical condition of over 220 books. My student interns, in addition to helping create a digital archive, are tasked with bringing the history of libraries and of the book to the general public. They run the Instagram feed, selecting images that they believe will appeal both to those already interested in early modern books and to those who may have had less exposure to the subject, but who will nevertheless enjoy specific posts for their artistic, scientific, or other content. They have made connections to Harry Potter, recent hurricanes, the Templars, secret knowledge, Halloween, and (a personal favorite) "Catholic stuff you should know." Among our more popular posts from the first year (2018-19) were close-ups of marginalia and a map of Rome; this year (2019-20), a book on alchemy and an English-language recusant text have been very popular.

When I first envisioned the EJLPP, I discussed several considerations, including the public face of the project, with Dr. Kyle Roberts, whose Jesuit Libraries Provenance Project (https://jesuitlibrariesprovenanceproject.com/ [accessed January 8, 2020]) focused on the collection of Loyola University Chicago. Like Roberts's JLPP, we had originally planned to use Flickr as our digital archive; the platform is very flexible and allows for tagging, sorting, slideshows, etc. However, in the second half of 2018, the company announced restrictions on the number of images one account could contain without payment. As there is no continuous funding for the EJLPP, we opted instead to make Georgia Southern's Digital Commons the archive; but it is very much an archive, with fewer features than Flickr. We plan to continue to use Instagram and to expand our audience, and have discussed other potential social media platforms. Our presence on Facebook is less active. We use that site to appeal to the many groups active in book and printing history, and in so doing have discovered other exciting work on libraries, Jesuit and otherwise, around the word. Finally, our web page is designed to provide access to the spreadsheets containing information on all of the books, including those for which we have no photographs-either those we have not seen in person or those we have seen but for which we do not have permission to upload images (nearly 4,100 in total).

The ongoing study is shaped by both my own goals and the interests of the students working with me. Graduate students in public history come to the project with great enthusiasm and ideas, and the ability to pursue their own projects for their non-thesis graduation requirement. Undergraduates with interest in the history of the book, as well as those with language skills in Latin and German, have also eagerly stepped up, as have others with the desire to 
pursue public history on the graduate level. My first student, Rudy Bond (MA, 2019), worked with me to create a larger vision of the project and to begin the Flickr archive and Instagram feed. Jasmine Webb (BA, 2019), with the help of Georgia Southern (Statesboro campus) librarian Jennifer Gerrald, started our Digital Commons archive. In the summer of 2019, three undergraduate history majors picked up the work: Samantha Sanchez made progress in uploading images and textual information to Digital Commons, while Michael Sullivan and Nesha Wright began a biographical database for authors and handled the Instagram feed. In the fall semester of 2019, Christopher Camp (current undergraduate) and Lauren Della Piazza Hartke (current graduate student) are working to complete the Digital Commons archive and to continue posting on Instagram.

Della Piazza Hartke will also be using GIS technology to begin mapping the movement of books. Because this is a very large endeavor, she will focus on the texts associated with the Low Countries and England. Our first foray into such an enterprise will no doubt teach us a great deal about how to progress in the future to include other geographical locations. An example of where this kind of data mining can take us is found in the 2015 dissertation of Miguel Ángel Sánchez Herrador, "La biblioteca del Colegio de la Encarnación de los jesuitas de Montilla" (The library of the Jesuit College of the Incarnation in Montilla), in the "Mapa de distribución de los libros en ciudades europeas" (Map of the distribution of books in European cities), which shows where in Europe the books held in the Spanish foundation at Montilla were printed, sorted into three color-coded groups: fewer than ten editions; between ten and one hundred editions; and more than one hundred editions. ${ }^{21}$ Eventually, I hope to trace the paths of individual books, the prominence of specific printers, and the distribution of given editions.

The most developed portion of the project so far depends on collecting provenance and usage information from books I can examine physically, and on searching library catalogues in the US and Europe for provenance information. The least developed portion, to which I hope to dedicate more attention once the photographic archive is complete, involves those manuscript inventories of pre-suppression Jesuit college and professed house collections in Italy and Belgium. I have not completed the transcription or analysis of these documents, but I have made those that I did transcribe available at my website. Building on work I have already published, I plan to analyze the titles I found there (for example, by author, language, and subject), and to compare

21 Universidad de Córdoba, Facultad de Filosofía y Letras, Departamento de Ciencias de la Antigüedad y de la Edad Media, 1: 86. 
individual collections to each other, to the information I have collected from modern libraries, and to those sources that were created in order to guide the Society on its teaching and reading, for example the Ratio studiorum and the Bibliotheca selecta. ${ }^{22}$ Studies of publishers, marginalia, and expurgations should also be quite fruitful. I have devised several future writing projects related to the EJLPP, including a forthcoming article on what texts European Jesuits might have read before embarking on missions. I have begun sketching out other pieces on the local aspects of the collections (i.e. how many texts were available in the language of the region where the library was based; how many focused on local history, geography, botany; etc.) and the subjects in the libraries. Overall, I am employing three approaches to focus the interpretive work: comparative, considering several European countries; intellectual, discussing the development of academic disciplines, printing, and the relationship between book collections and teaching; and longitudinal, exploring the impact of the educational work of one of the most prominent of the Catholic religious orders. My goal is an improved understanding of the materials the Jesuits and their students used in the pursuit of intellectual excellence and religious orthodoxy, focusing primarily on institutions in central Italy, northern Spain, Belgium and the Netherlands, and England, before the eighteenth century.

The EJLPP is not open source, but I provide access to the spreadsheet and to photographs under the Creative Commons licensing rules detailed at the Digital Commons page, and via my website. ${ }^{23}$ As of this writing, I have begun discussion about specific forms of cooperation with colleagues sharing my interest in Jesuit provenance and library history, and hope to develop a method that allows for input from others in the scholarly community without either compromising or unnecessarily complicating matters of copyright, access, etc. I believe others who cannot contribute will be interested in using the data for analyzing ideas I have not yet dreamt up.

I also continue to collect information, both electronically and in person. The EJLPP is an ongoing attempt to investigate multiple angles of the "republic of letters," and to make both raw data and interpretations of those data available to the public. We hope that scholars in different disciplines can use the materials we have uncovered to produce a more nuanced understanding

22 Comerford, “Jesuit Tuscan Libraries," 515-31.

23 I use the CC BY-NC-ND 4.o (Attribution-NonCommercial-NoDerivatives 4.0 International) license, which allows non-commercial public use of the images and attached information so long as said images and information are presented only in their original form and are properly attributed. 
of Jesuit education and preparation, intellectual life, and other activities in Europe between 1540 and 1773 . In addition, we believe that the information we have catalogued will be of use to scholars of early printing, the Reformations, Enlightenment philosophy and theology, the Atlantic world, cartography, linguistics, and the history of science, medicine, and technology. We invite you to explore our data and ask that, should you use it as allowed under the Creative Commons license, you let us know the ways in which it has enriched your work. 